\title{
A Geografia do Brasil Africano, o congo e a Bélgica- Uma aproximação
}

Rafael Sanzio Araújo dos Anjos

p. $01-25$

Como citar este artigo:

Anjos. R,S,A. Rafael Sanzio Araujo dos Anjos - A geografia do Brasil Africano, o Congo e a Bélgica, uma aproximação

revista

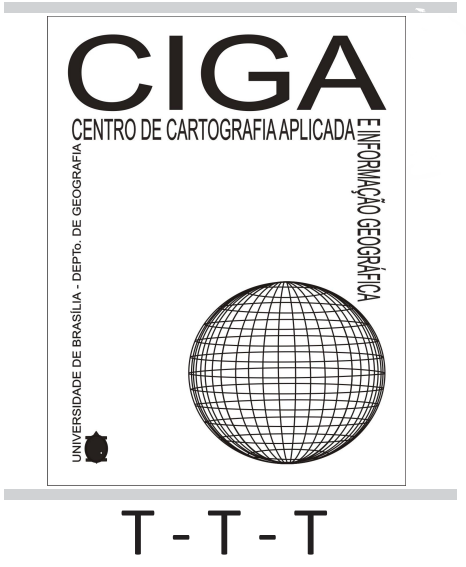

Revista Eletrônica: Tempo - Técnica - Território, V.1, N.3 (2010), 1:25 ISSN: $2177-4366$

DOI: https:// doi.org/10.26512/ ciga.v1i3.15787
Revista Eletrônica: Tempo - Técnica - Território, v.1, n.3 (2010), p. 1:25 ISSN: 2177-4366.

DOI: https://doi.org/10.26512/ciga.v1i3.15787

Disponível em:

http://inseer.ibict.br/ciga/index.php/ciga/article/viewFile/288/207

Este obra está licenciado com uma Licença Crea tive Commons Atribuição-NãoComer cial 4.0 Inter nacional. 


\title{
A GEOGRAFIA DO BRASIL AFRICANO, O CONGO E A BÉLGICA - UMA APROXIMAÇÃO (*)
}

\section{RAFAEL SANZIO ARAÚJO DOS ANJOS}

Geógrafo, Doutor em informações espaciais (epusp-br/ird-fr) / pós-doutoramtno em cartografia'étnica no museu real da áfrica central (mrac-tervuren-bélgica), prof. Associado do depto. De geografia / diretor do centro de cartografia aplicada e informação geográfica da universidade de Brasília.

Telefax: (61) 3107-7242 E-mail: quilombo@unb.br

RESUMO: Utilizando referências da geografia e da cartografia, o paper busca auxiliar na ampliação das reflexões sobre a relevância da diáspora africana para o entendimento da distribuição da população de matriz africana brasileira, assim como, a importância da República Democrática do Congo (África) e da Bélgica (Europa), como exemplos de unidades políticas com referências historiográficas fundamentais nesse processo de conhecimento básico para o "equilíbrio social” do "Brasil africano contemporâneo".

\begin{abstract}
Using the references of the geography and the cartography, the paper seeks to assist in the expansion of the reflections on the relevance of the african diaspora to the understanding of the distribution of the Brazilian population of African origin, as well as the importance of the Democratic Republic of Congo (Africa) and Belgium (Europe), as exemplifying units polities with fundamental historiographical references in this process of basic knowledge for the "social balance" of "contemporary african Brazil."
\end{abstract}

\section{INTRODUÇÃO}

A África é o continente mais importante no suporte e na manutenção da estruturação do mundo nos últimos cinco séculos, particularmente na formação do Novo Mundo, a América. O Brasil, por sua vez, é a unidade política contemporânea que registra as maiores estatísticas de importação forçada de contingentes populacionais africanos ao longo dos séculos XVI a XIX. Dessa forma, o território africano é um componente fundamental para 
uma compreensão mais apurada das questões que envolvem o papel da população de ascendência africana na sociedade brasileira. Por isso, o Brasil continental, plurirracial, multicultural e com uma historicidade em processo de reconstrução e uma diversidade étnica com conflitos, tem ainda, o desafio de assumir decisivamente a nação multiétnica resultante destes séculos de "conivência" com a África. Estes são pontos estruturais que preconizam a busca de equilíbrio na sociedade brasileira e no seu território e, sobretudo um tratamento ético. Por isso mesmo, se fazem necessário, interpretações mais consistentes das origens das suas populações nos primórdios da suas formações; de um melhor entendimento e representação da dinâmica desta diáspora no espaço e uma melhor configuração da sua identidade territorial ancestral.

Apesar dessa referência histórica da matriz africana presente no país, a incorporação verdadeira, o respeito e o espaço da cultura africana no Brasil, continua sendo uma das questões estrutrais do país, que ainda merece investigação, conhecimento e ação. Nesse sentido, as demandas para compreensão das complexidades da dinâmica da nossa sociedade são grandes e existem poucas disciplinas mais bem colocadas do que a geografia e a cartografia para auxiliar na representação e interpretação das inúmeras indagações desse momento histórico.

A geografia é a ciência do território e este componente fundamental, a terra, o terreiro num sentido amplo, continua sendo o melhor instrumento de observação do que aconteceu, porque apresenta as marcas da historicidade espacial; do que está acontecendo, isto é, tem registrado os agentes que atuam na configuração geográfica atual e o que pode acontecer, ou seja, é possível capturar as linhas de forças da dinâmica territorial e apontar as possibilidades da estrutura do espaço no futuro próximo. O território é na sua essência um fato físico, político, social, categorizável, possível de dimensionamento, onde geralmente, o Estado está presente e estão gravadas as referências culturais e simbólicas da população. Não podemos perder de vista que a geografia é a área do conhecimento que tem o compromisso de tornar o mundo e suas dinâmicas compreensíveis para a sociedade, de dar explicações para as transformações territoriais e de apontar soluções para uma melhor organização do espaço. A geografia é, portanto, uma disciplina fundamental na formação da cidadania do povo brasileiro, que apresenta uma heterogeneidade singular na sua composição étnica, socioeconômica e na distribuição espacial. 
Os mapas, por sua vez, são as representações gráficas do mundo real, se firmam como ferramentas eficazes de interpretação e leitura do território, possibilitando revelar a territorialidade das construções sociais e feições naturais do espaço e, justamente por isso, mostram os fatos geográficos e os seus conflitos. Estes possibilitam revelar graficamente o que acontece na dinâmica do espaço e tornam-se cada vez mais imprescindíveis, por constituírem, uma ponte entre os níveis de observação da realidade e a simplificação, a redução, a explicação e de pistas para a tomada de decisões e soluções dos problemas. Não podemos perder de vista que um mapa não é o território, mas que nos produtos da cartografia estão as melhores possibilidades de representação e leitura da história do território.

Neste paper buscamos auxiliar na ampliação das reflexões sobre a relevância da diáspora africana para o entendimento da distribuição da população de matriz africana brasileira, assim como, a importância da República Democrática do Congo (África) e da Bélgica (Europa), como exempos de unidades polítiícas com referências hitoriográficas fundamentais nesse processo de conhecimento básico para o "equilíbrio social" do "Brasil africano contemporâneo".

\section{A GEOGRAFIA DA DIÁSPORA AFRICANA E O BRASIL - UMA SÍNTESE}

O movimento histórico das grandes navegações, deve ser entendido como uma conseqüência direta do processo geográfico de dominação territorial desenvolvido, amadurecido e implementado pelo continente europeu. O horizonte geográfico das terras emersas vai ser ampliado de forma signgificativa pelos novos encontros de culturas, identidades e territorialidades. Como resultado, o mapa do mundo vai ser profundamente modificado nos séculos XV, XVI, XVII, XVIII E XIX, sobretudo pelos novos territórios a ele incorporado e as "novas" fronteiras constituídas e impostas. Este período da história dos seres humanos vai se caracterizar por uma nova fase de relações entre estes e a natureza. Os trópicos eram vistos pelo europeu como um mundo que poderia lhe oferecer um conjunto de produtos que não existiam no seu continente e esta estratégia representava um estímulo à política mercantilista, ao desenvolvimento do capitalismo comercial e ao fortalecimento do Estado. 
Não eram somente as riquezas da África que interessavam a Europa Moderna, os seres humanos, também eram necessários aos colonizadores para o cultivo e a esploração das minas. Instaura-se assim um novo período de escravidão humana, associada à acumulação de capitais, estruturado num sistema político, jurídico e econômico que vai permitir o desenvolvimento de uma gigantesca empresa comercial, possibilitando a expansão do capitalismo. O tráfico demográfico forçado do continente africano para a América foi, durante quase quatro séculos, uma das maiores e mais rentosas atividades dos negociantes europeus, a tal ponto de se tornar impossível precisar o número de africanos retirados de seu habitat, com sua bagagem cultural, a fim de serem, injustamente, incorporados às tarefas básicas para formação de uma nova realidade. Entre 12 e 13 milhões de seres humanos africanos transportados é uma referência, apesar das pesquisas divergirem, ainda atualmente, sobre os registros quantitativos nessa diáspora africana. Entretanto, é consenso na comunidade científica que a dinâmica do tráfico trouxe problemas de despovoamento em numerosas áreas do continente.

É importante lembrar que o conceito geográfico de diáspora tem haver com a referência de dispersão de uma população e das suas matrizes culturais e tecnológicas. Ao longo da história podemos identificar a construção de territórios pela mobilidades das migrações, tanto de forma voluntária quanto das migrações forçadas. Na África, podemos caracterizar alguns destes grandes movimentos demográficos, a começar pela primeira diáspora, que corresponde ao processo espacial milenar de povoamento e ocupação do próprio continente e, posteriormente, para outras terras emersas do mundo. $\mathrm{O}$ fenômeno espacial que abordamos, nesta oportunidade está ligado aos séculos de deslocamentos, geralmente, denominado, "tráfico negreiro" para a América (Novo Mundo), fruto de longos períodos de migração forçada do continente africano, contexto propulsor do sistema escravista e base fundamental do capitalismo primitivo. 


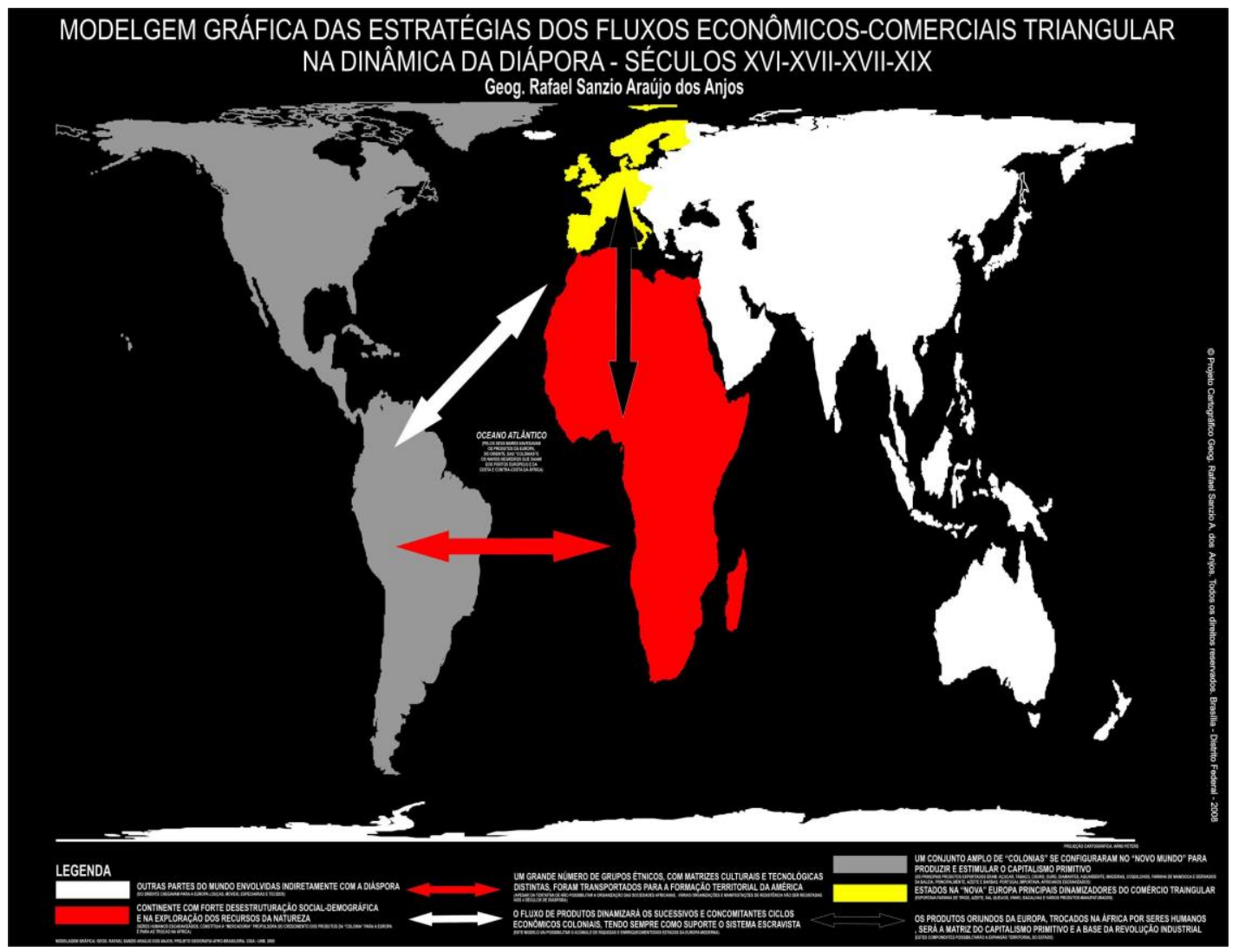

Figura 1: Modelagem gráfica das estratégias dos fluxos econômicos comerciais triangular na dinâmica da Diápora

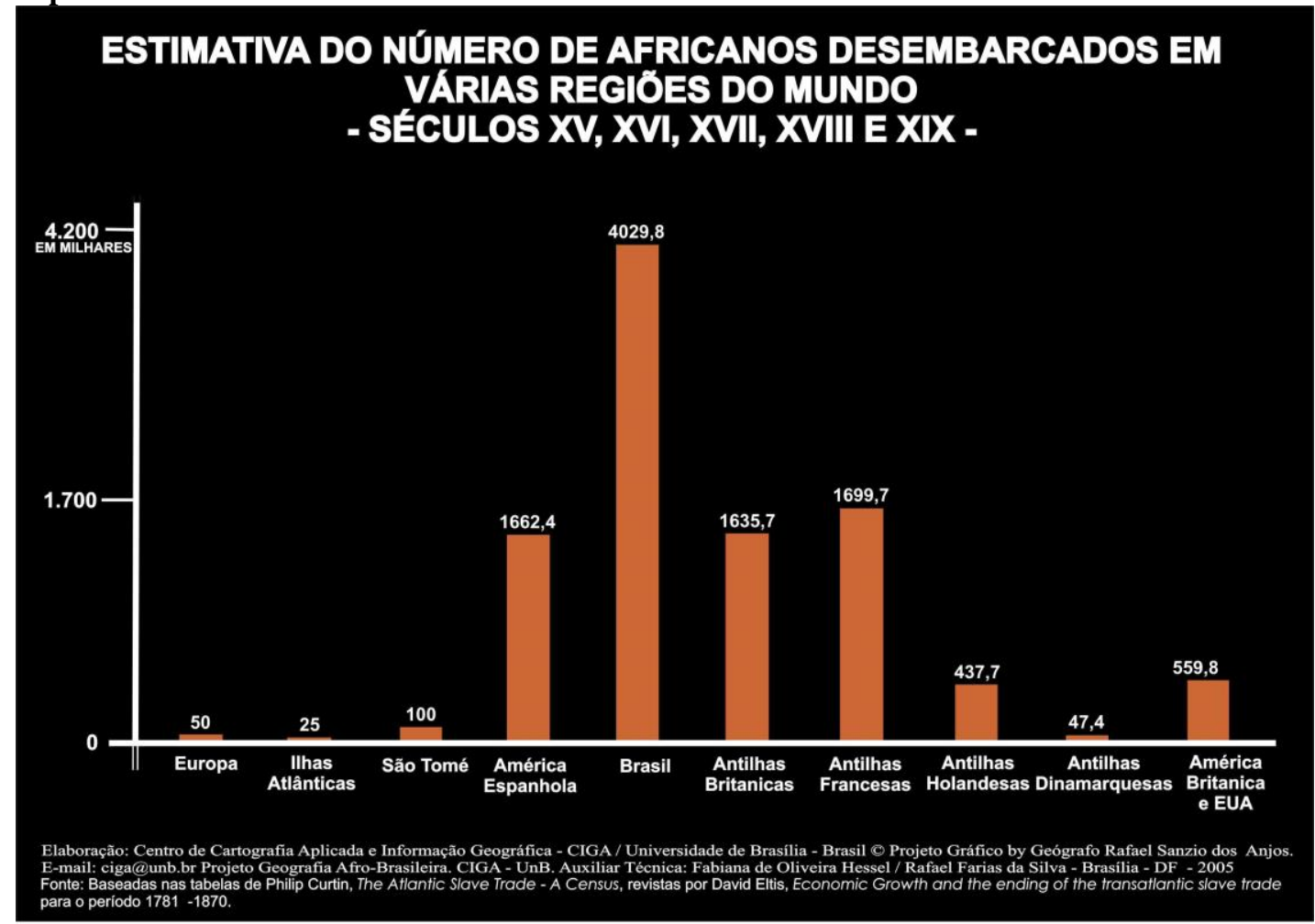

Figura 2: Gráfico estimativa do número de africanos desembarcados em várias regiões do mundo

Revista Eletrônica: Tempo - Técnica - Território, V.1, N.3 (2010), P. 1:25 ISSN: 2177-4366 


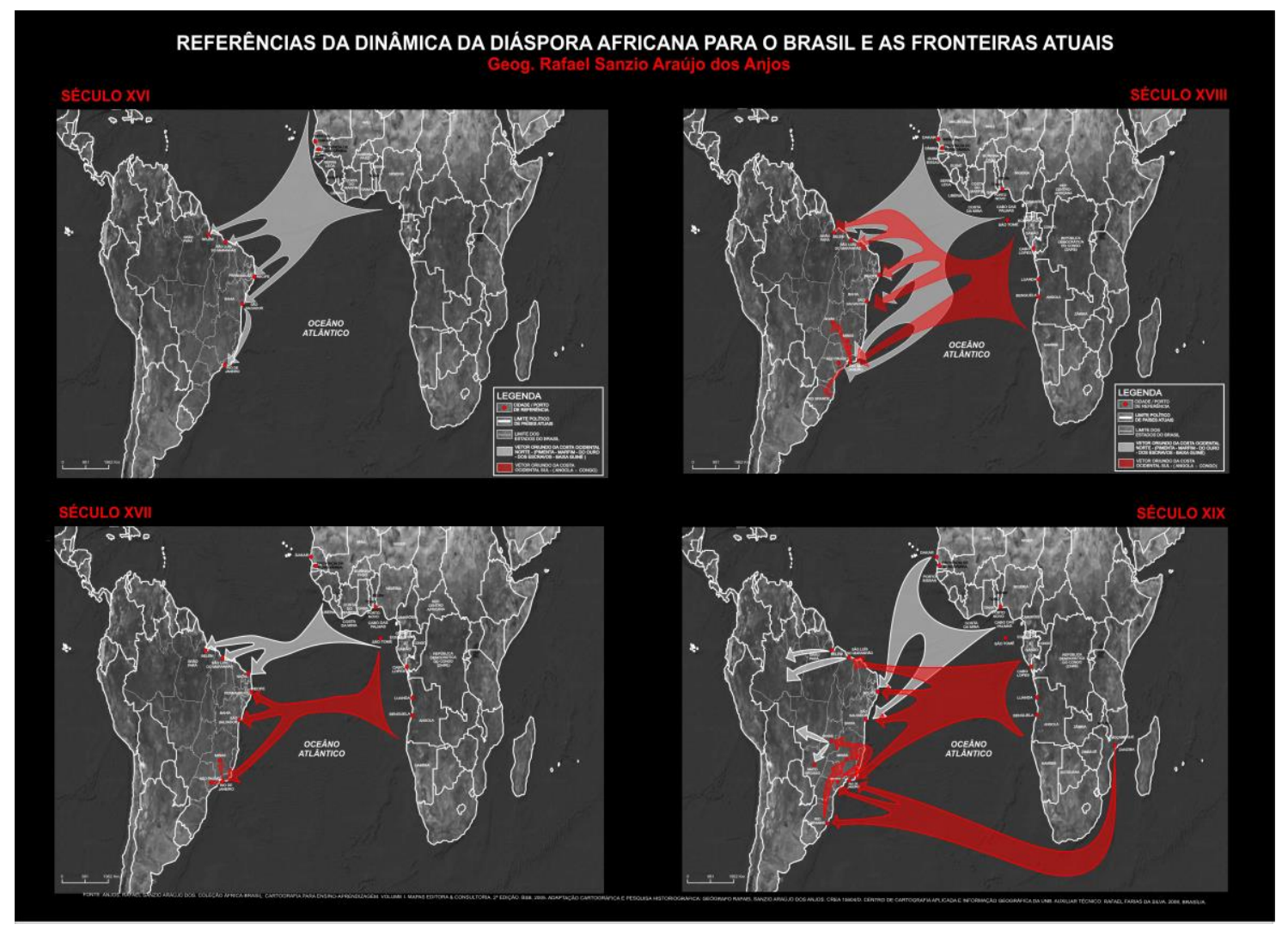

Figura 3: Referência da dinâmica da diáspora Africana para o Brasil e as fronteiras atuais 


\title{
BRASIL REFERÊNCIAS TERRITORIAIS DOS PRINCIPAIS CICLOS ECONÔMICOS COLONIAIS
}

\author{
Geog. Rafael Sanzio Araújo dos Anjos
}

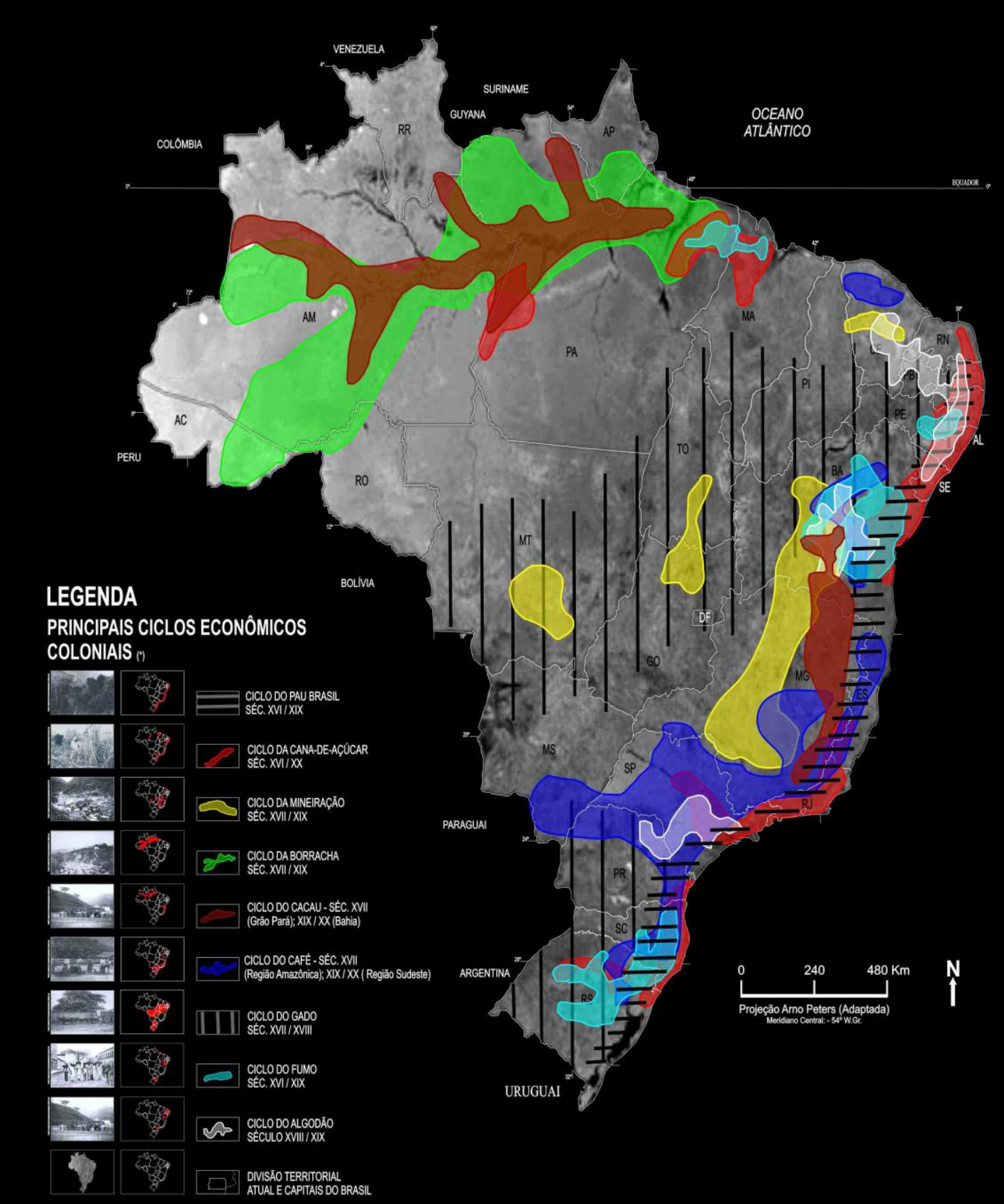

(") Fronteiras aproximados das áreas com atvidades econỏmicas desenvolidas, principalmente, durante os sécullos do sistema escravista no Brasil, que tinha como suporte base de produçăo, a força do trabalho e as tecrnologias de referência afticana.

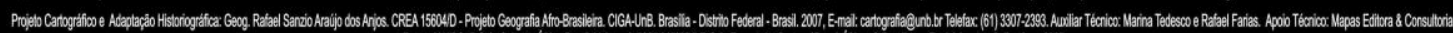

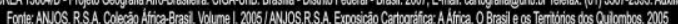

Figura 4: Brasil: Referências territoriais dos principais ciclos econômicos coloniais 


\section{BRASIL \\ PRINCIPAIS ZONAS E SÍTIOS DE QUILOMBOS E REVOLTAS DE POPULAÇÕES AFRICANS E DE DESCENDENTES NO TERRITÓRIO BRASILEIRO - SÉCULOS XVI / XIX \\ Geog. Rafael Sanzio Araújo dos Anjos}

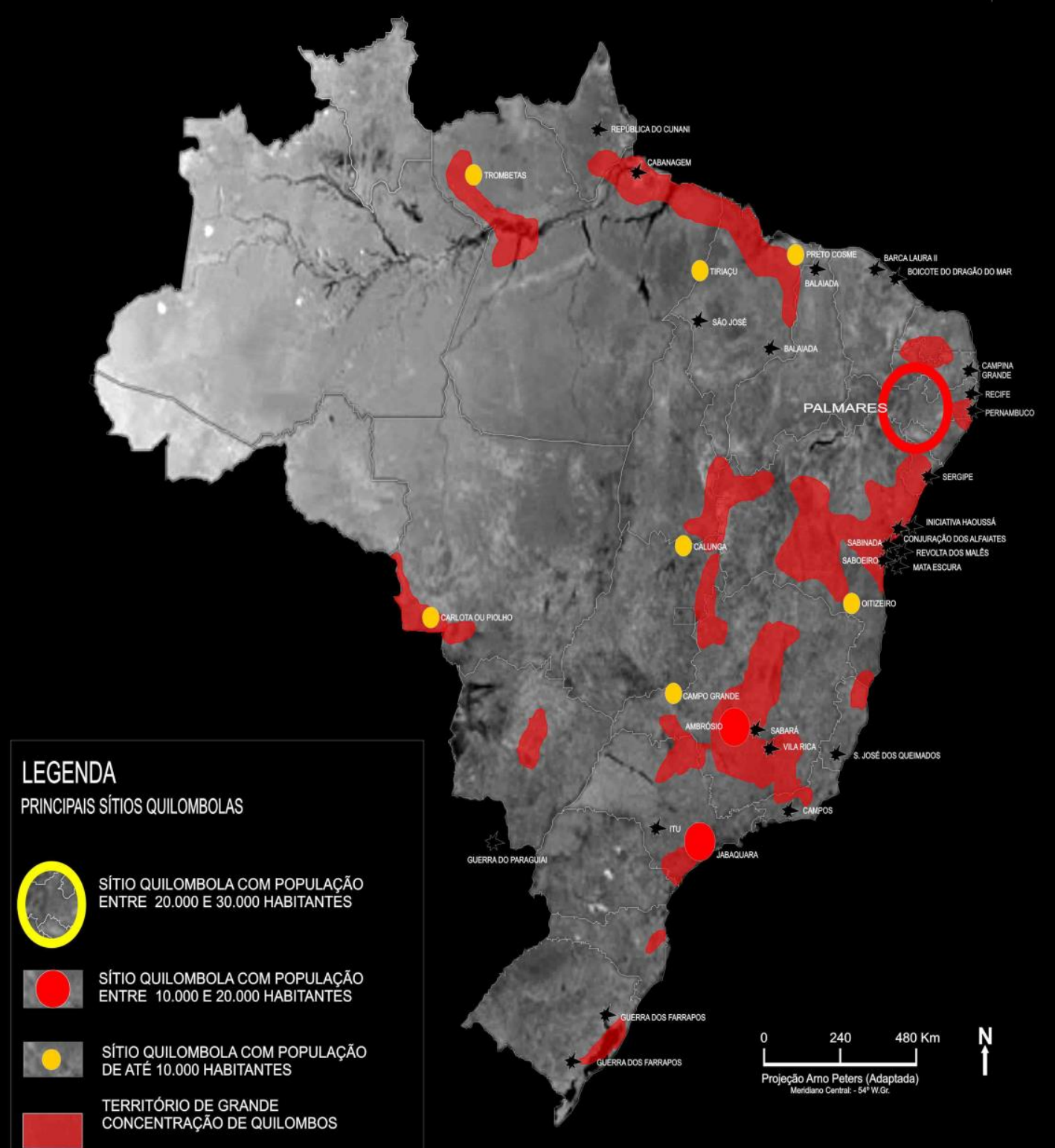

PRINCIPAIS REVOLTAS E INSURREIÇ̃ES

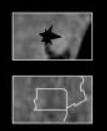

LOCAL APROXIMADO DA

OCORRÊNCIA/MANIFESTAÇÃO

DIVISÃO POLITICA DO BRASIL (1988)

๑) Base Cartográfica IBGE . 2000 ๑ Projeto Cartográfico e Adapataçẫo Historiográfica by Geog. Rafael Sanzio A. dos Anjos. Auxiliar Técnico: Daniel Zerbetto Vera/ Rafael Farias da Silva. Fonte: Anjos, R.S.A. Coleçăo Aáfirca-Brasil. Volume I. 2000 e 2005. Todos os direitos reservados. Brasillia - Distrito Federal - 2008

Revista Eletrônica: Tempo - Técnica - Território, V.1, N.3 (2010), P. 1:25 ISSN: 2177-4366 
Figura 5: Brasil: Principais zonas e sítios de Quilombos e revoltas de populações Africanas e de descendentes no território Brasileiro

Devemos ressaltar que foram as regiões geográficas do Brasil de interesse econômico europeu que detiveram os maiores fluxos de populações africanas escravizadas. A sequência dos mapas temáticos mostra uma representação gráfica das referências territoriais de origem na África nos quatro séculos do tráfico de populações e desestruturação de sociedades e Estados. No século XVI, a referência espacial principal são as regiões caracterizadas como Alta e Baixa Guiné. Esses foram trazidos principalmente para as regiões açucareiras de Pernambuco e Bahia, mas também, foram levados para o Maranhão e para o Grão-Pará. Os territórios africanos atingidos pelo tráfico nesse período atualmente correspondem aos limites internacionais dos seguintes países: Serra Leoa, Senegal, Guiné, Guiné-Bissau, Nigéria, Benin, Burquina Faso, Gana, Costa do Marfin, Libéria, Mali e Gâmbia.

No século XVII o tráfico vai ser dinamizado na Costa de Angola, transportando povos africanos para a Bahia, Pernambuco, Alagoas, Rio de Janeiro, São Paulo e regiões do centro-sul do Brasil, e na Costa da Mina, com fluxos para as províncias do Grão-Pará, Maranhão e o território atual do Rio Grande do Norte. A antiga Costa da Mina compreende atualmente os territórios dos seguintes países: Costa do Marfin, Libéria, Burquina Fase, Mali, Niger, Congo, Gana, Togo, Benin, Nigéria e Camarões. A conhecida Costa de Angola corresponde atualmente aos seguintes países: Angola, Gabão, República Democrática do Congo e Guiné Equatorial. Nos séculos XVII e XVIII, vão se constituir as mais importantes e duradouras extensões territoriais das rotas do tráfico negreiro: as Costas da Mina e de Angola. É nesse período que vão ocorrer os maiores volumes de povos africanos transportados para o território brasileiro.

A primeira metade do século XIX caracterizou-se pelos vários tratados visando abolir o tráfico negreiro, o que no Brasil só ocorreu efetivamente em 1850. Pelo quadro de ilegalidade e clandestinidade, os dados estatísticos dos movimentos demográficos são bem imprecisos. Os espaços geográficos da África atingidos por esse último ciclo têm correspondência, na atualidade, aos territórios dos seguintes países: Gana, Togo, Benin, Nigéria, Gabão, Congo, Angola, República Democrática do Congo, Moçambique e Madagascar. Esse é o período em que são desfeitas as ligações bilaterais entre os continentes africano e americano, sendo destruídas as rotas do tráfico triangular entre a 
América, a África e a Europa. Entretanto, o Brasil por 66 anos e os Estados Unidos por mais 90 anos, continuaram escravistas depois da independência.

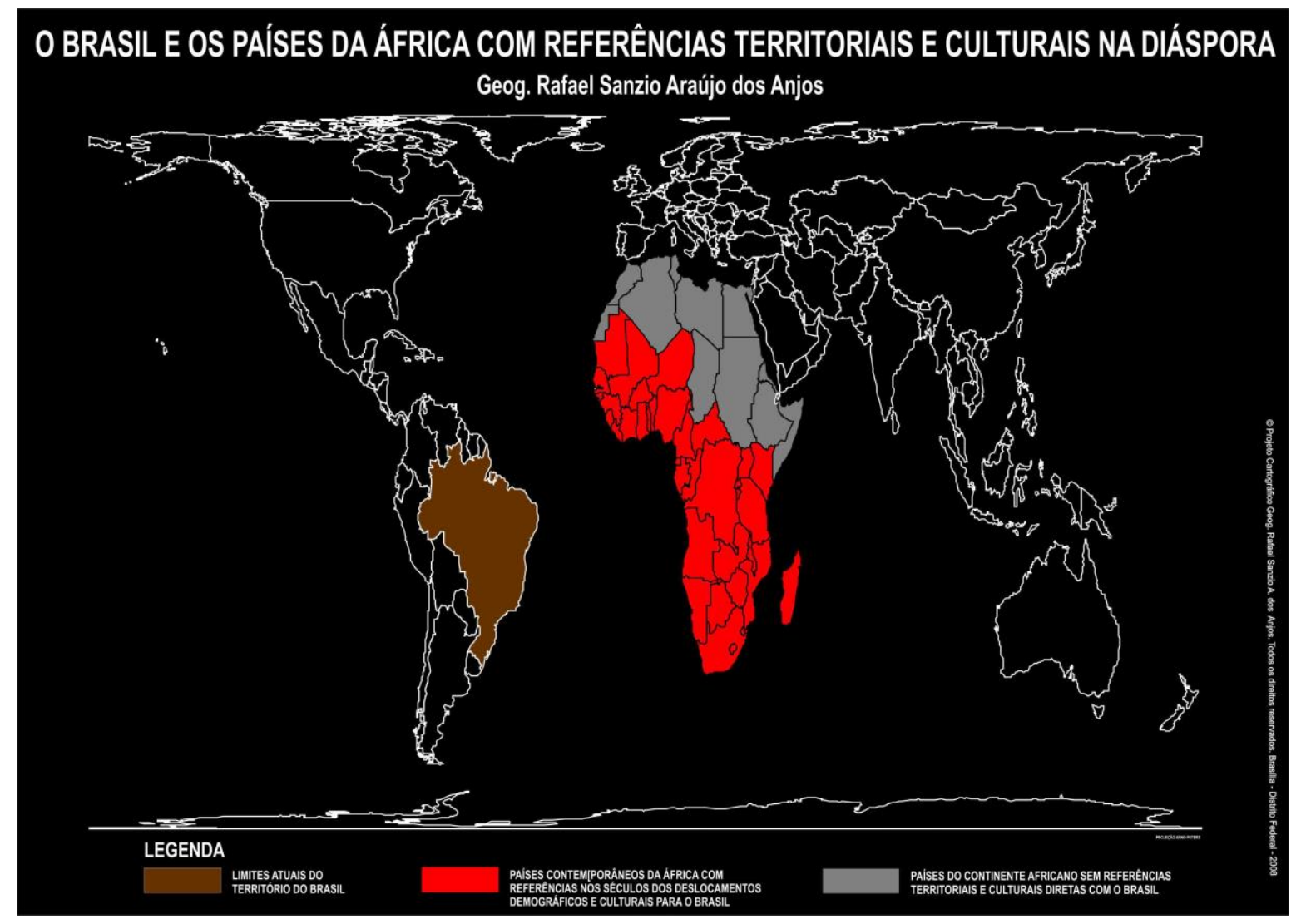

Figura 6: O Brasil e os países da África com referências territoriais e culturais na Diáspora

A manutenção dessa estruturação política, econômica e territorial por quase quatro séculos no território brasileiro e a quantidade de africanos importados até 1850, não devidamente quantificada, mostra como a consolidação da sociedade escravagista conseguiu estabilizar-se e desenvolver-se mesmo com os conflitos políticos e contradições econômicas e sociais. No "Brasil Colônia”, o quilombo era uma reconstrução e elaboração concreta de um tipo de organização territorial existente na África Meridional, que apresenta variadas significações e, uma delas é um estado permanente de guerra. A palavra aportuguesada quilombo, tem sua origem na estrutura da língua bantu (kilombo) e pode ser entendido ainda, como acampamento guerreiro na floresta, o nome de uma região Administrativa de Angola, habitação no território do antigo Reino do Congo; lugar para 
estar com Deus na Região Central da Bacia do rio Congo e, significa, ainda, na Região Centro-Norte de Angola filho de preto que não é preto. A grande extensão dos povoados "livres", com uma forma de organização territorial de matriz africana, que vão se desenvolver nas margens brasileiras do Oceano Atlântico, têm em comum a referência de um espaço seguro e protegido, não necessariamente isolado, com igualdade de condições na maioria das relações comunitárias, de liberdade de acesso à terra e de uma base possível de ter confrontos e guerras pela manutenção do espaço "livre". Neste sentido o quilombo africano e o quilombo americano apresentam semelhanças fundamentais.

Algumas considerações em torno das referências etnográficas da África Sub-Saariana com registros no Braisl e expressão espacial da população afro-brasileira contemporânea são temas tratadas no item a seguir.

\section{A CARTOGRAFIA DA POPULAÇÃO AFRO-BRASILEIRA - UMA INTRODUÇÃO}

O processo de pulverização das distintas matrizes africanas nmas extensões do território colonial tinha, também, como estratégia, dificultar a organização, extinguir a língua de origem e impossibilitar a continuidade das culturas, ou seja, foram criados dispositivos reais para que as populações oriundas da África perdessem as suas referências identitárias e, por conseguinte, houvesse uma diluição da identidade étnica africana no Brasil. São "trazidos" para constituir a formação, a expansão e a ocupação efetiva do território brasileiro seres humanos: Minas, Congos, Ombundos, Bacongos, Ovibundos, Monjolos, Balundos, Jejes, Angolas, Anjicos, Lundas, Quetos, Hauças, Fulas, Ijexás, Jalofos, Mandingas, Anagôs, Fons, Ardas, dentre muitos outros, que possibilitaram o que podemos simplesmente denominar de afro-brasileiros, brasileiros de matriz africana ou população de ascendência africana. Por exemplo, as populações de matriz Bantu, com origem na África Central e os Iorubás, também denominados, Nagôs, oriundos da África Ocidental apresentam registros e características relevantes no cotidiano do "Brasil Real".

O país sabe com clareza que, no período entre 1871 e 1920, 3.390 .000 imigrantes europeus chegaram ao país, dos quais: 1.373 .000 eram italianos; 901.000, portugueses e 500.000, espanhóis. Muitos europeus no Brasil vão ocupar territórios onde já estavam estabelecidas populações africanas ou de seus descendentes, como, por exemplo, a 
ocupação de imigrantes italianos (1880) no sítio de Sapucaí, na região do grande Quilombo do Campo Grande, na antiga Província de Minas Gerais. É importante notar que esse número se aproxima dos quase 4.000 .000 africanos que foram retirados de seu habitat natural e trazidos para o Brasil oficialmente entre 1520 e 1850. Isso porque as referências espaciais, temporais e quantitativas do período clandestino do tráfico ainda estão para serem caracterizados pela historiografia brasileira.

Esse é mais um fator geográfico que colabora para a falta de uma referência ancestral de origem da população brasileira de referência africana, com interferências profundas na sua cidadania e no sentimento de pertencimento territorial. Afirmar para esse contingente que os seus antepassados foram "trazidos" do continente africano é vago, sem consistência, desrespeitoso, quando se trata de uma extensão com mais de $30.000 .000 \mathrm{Km} 2$, com contextos territoriais de centenas de antigos reinos, impérios e grupos étnicos desconhecidos da historiografia oficial do país. Essa demanda secular, que possibilitaria uma ligação espacial mais referenciada e mais precisa na África, continua sem resposta satisfatória e nem perspectiva de solução institucional.

Dessa forma, um dos grandes desafios das pesquisas territoriais destinadas à diáspora africana está no silêncio das estatísticas do tráfico e na identificação da referência territorial, portanto, do lugar de origem dos grupos de africanos que entravam no Brasil. Entretanto, tomando como premissa as indicações conhecidas dos sítios e regiões da dinâmica das rotas do tráfico no Brasil ao longo dos quatro séculos do comércio de populações africanas (Anjos, 2000); os mapeamentos realizados por Castro (2001) sobre a fala das distintas sociedades da África no Brasil e os espaços onde se instalaram os ciclos econômicos colônias (Anjos, 2006), foi possível ser feito um cruzamento dessas variáveis territoriais e inferir sobre a expressão etnográfica da África Sub-Saariana no Brasil dos séculos XVI até o XIX. Alguns contextos historiográficos e territoriais são relevantes:

1. No século XVI, que registra as primeiras levas das populações africanas para o trabalho forçado no ciclo econômico da cana-de-açúcar, no eixo territorial do Recôncavo da Bahia, ao norte de Pernambuco (onde se incluí os atuais Estados de Alagoas e Sergipe) os grupos étnicos predominantes vão ser os Bantus, da Costa de Angola, e os Jeje-Mina, da Costa da Guiné, também conhecida como Costa do Ouro, Costa do Marfim e a Costa dos Escravos. Nesse século a expansão do sistema escravista atinge o Maranhão e o Grão Pará; 
2. A Costa de Angola, no século XVII, vai se caracterizar pela intensidade do tráfico, fato que vai incrementar a entrada de grande contingente de povos Bantus na região açucareira do Brasil, expandindo-se para o sudeste (Rio de Janeiro, São Paulo, Minas Gerais) e Goiaz, no centro da "Colônia". O tráfico se transferiu temporariamente para o Golfo da Guiné (Costa da Mina) e povos Jeje-Mina vão ser transportados para territórios já conhecidos como o Maranhão e o Grão-Pará, assim como, uma expansão no nordeste na direção do atual Estado do Rio Grande do Norte;

3. No século XVIII estão os registros das maiores quantidades de seres humanos do continente africano na condição de escravizados e transportados para o Brasil. Distintos grupo de líguas Bantus, como os Congos, Cabindas e Angolas, principalmente, vão se expandir pelo território brasileiro em formação, com registros em quase todos os portos da costa brasileira. Da Costa da Guiné foram trazidos para a Bahia os Nagôs-Iorubás e os Hauçás (populações sudaneses islamizados ou não);

4. O século XIX tem a referência de ser o da abolição do tráfico negreiro, entretanto, o Brasil vai continuar de forma clandestina a dinâmica demográfica de transposição de populações oriundas da Áfricas. Grupos Bantus da Costa de Angola vão ser transportados para portos no Maranhão, Pernambuco, Rio de Janeiro, São Paulo e Bahia e da Contra Costa da África, da região de Moçambique (os Macuas e Anjicos, principalmente), o direcionamento é para o centro do Brasil (Goiaz e Minas Gerais) São Paulo e Rio Grande do Sul. Da Baía do Benin, no Golfo da Guiné, serão retirados as últimas levas de seres humanos Jeje-Mina;

É importante destacar que as populações africanas sub-saariana não foram responsáveis somente pela ocupação efetiva do território brasileiro e pela mão-de-obra, eles marcaram e marcam, de forma irreversível, a nossa formação social, tecnológica, demográfica e cultural que, ao longo desses séculos, foi preservada e recriada, mesmo com as políticas contrárias do sistema. Vários setores da população brasileira contemporânea são vítimas de discriminação e preconceitos de toda a ordem. Entre os tipos de discriminação, a étnica, que atinge particularmente o contingente de ascendência africana no país, é sem dúvida a de maior extensão social e territorial, devido à grande expressão demográfica. Os problemas se revelam já quando se quer saber qual o número real de "negros" ou da população de ascestralidade na África. É importante lembrar que a palavra "negro" tem 
historicamente um significado pejorativo, de algo ruim, que não é humano, mas associado a animal. Esse é um ponto de esclarecimento e correção histórica necessária e que requer uma ação política e educacional consequente, até porque, está incorporado de forma secular no pensamento social brasileiro. Se não fossem os negreiros e seus navios, comerciantes de seres humanos escravizados no continente africano, não existiria o "negro" e a "negra", tratados como mercadoria. Daí vem a "invenção" e promoção do engano secular denominado "raça negra".

A questão demográfica do "Brasil africano" tem ficado historicamente sem resposta adequada, isto porque os critérios de aferição racial oficiais levam à subestimação do numero real de cidadãos de matriz afro-brasileira que integram o país. O Instituto Brasileiro de Geografia e Estatística (IBGE) tem agrupado os indivíduos em brancos, pretos, amarelos e pardos, considerando brancos, pretos ou amarelos os que assim se declararem e os "outros" ficam classificados como pardos. A representaçao cartográfica da população recenseada como "preta" no Censo Demográfico realizado em 2000 pelo IBGE, nos revela a presença expressiva dessa população no país, destacando, principalmente que o Brasil urbano, peri-urbano e rural é significativamente afro-brasileiro. Existem evidências de que o contingente populacional brasileiro de matriz africana não é minoria e essa é mais uma estratégia do sistema de classificar os grupos discriminados de minorias, fazendo supor que estes atingem um número de pessoas menor que o de fato, utilizando-se de artifícios numéricos.

Se fizermos uma simulação e juntarmos as populações recenseadas pelo IBGE como "preta" e "parda" do Brasil no ano 2000, teremos 69.649.861 habitantes (47\% do contingente nacional). Não podemos perder de vista o que nos lembra o ditado popular: "de noite todos os gatos são pardos". Ou seja, associado ao "pardo" esta a indefinição da sua identidade, do seu lugar na sociedade, da sua referência ancestral, em síntese, da sua territorialidade. São milhares de homens, mulheres, crianças e idosos que sentem internamente, que não existe, ainda, um lugar definido na estrutura social do país. Por ser um contingente populacional oriundo de um processo secular de "mistura" étnica, as relações de valor que foram associados, sistematicamente, aos povos europeus, como o "modelo" de referência e aceito pelo sistema dominante, imprimem vários desajustes nas formas de pensar, de se inserir e de se enquadrar na sociedade brasileira. Se assumirmos 
que a população considerada como "parda" nesse Censo é de fato uma população mestiça que tem graus diferenciados de ascendência africana, ficará evidente que a população do Brasil com referência no continente africano não é minoria.

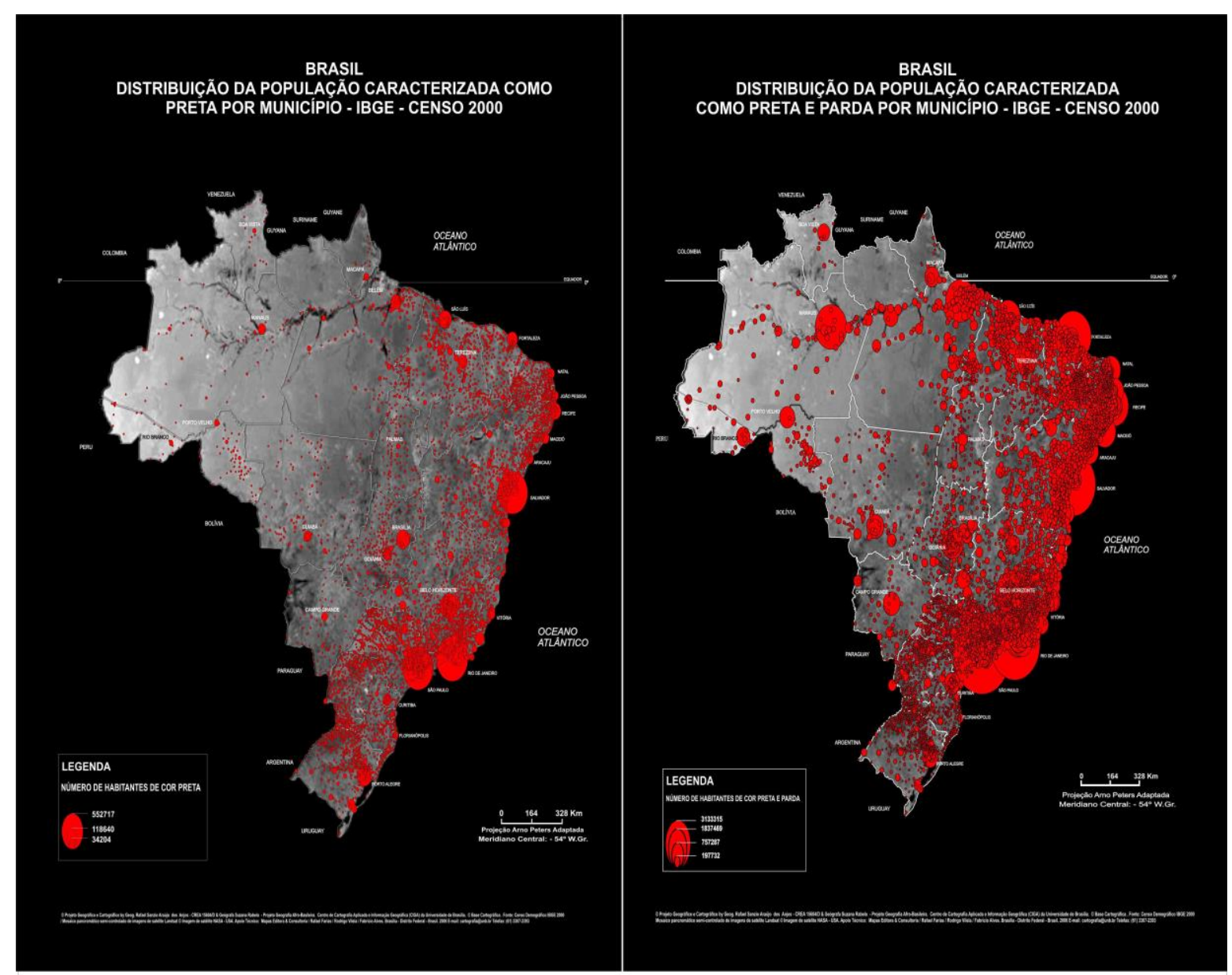

Figura 7: Brasil : Distribuição da população caracterizada como preta por município - IBGE 2000 


\section{O BRASIL E OS PAISES AFRICANOS ONDE SE FALAM LÍNGUAS BANTUS} Geog. Rafael Sanzio Araújo dos Anjos

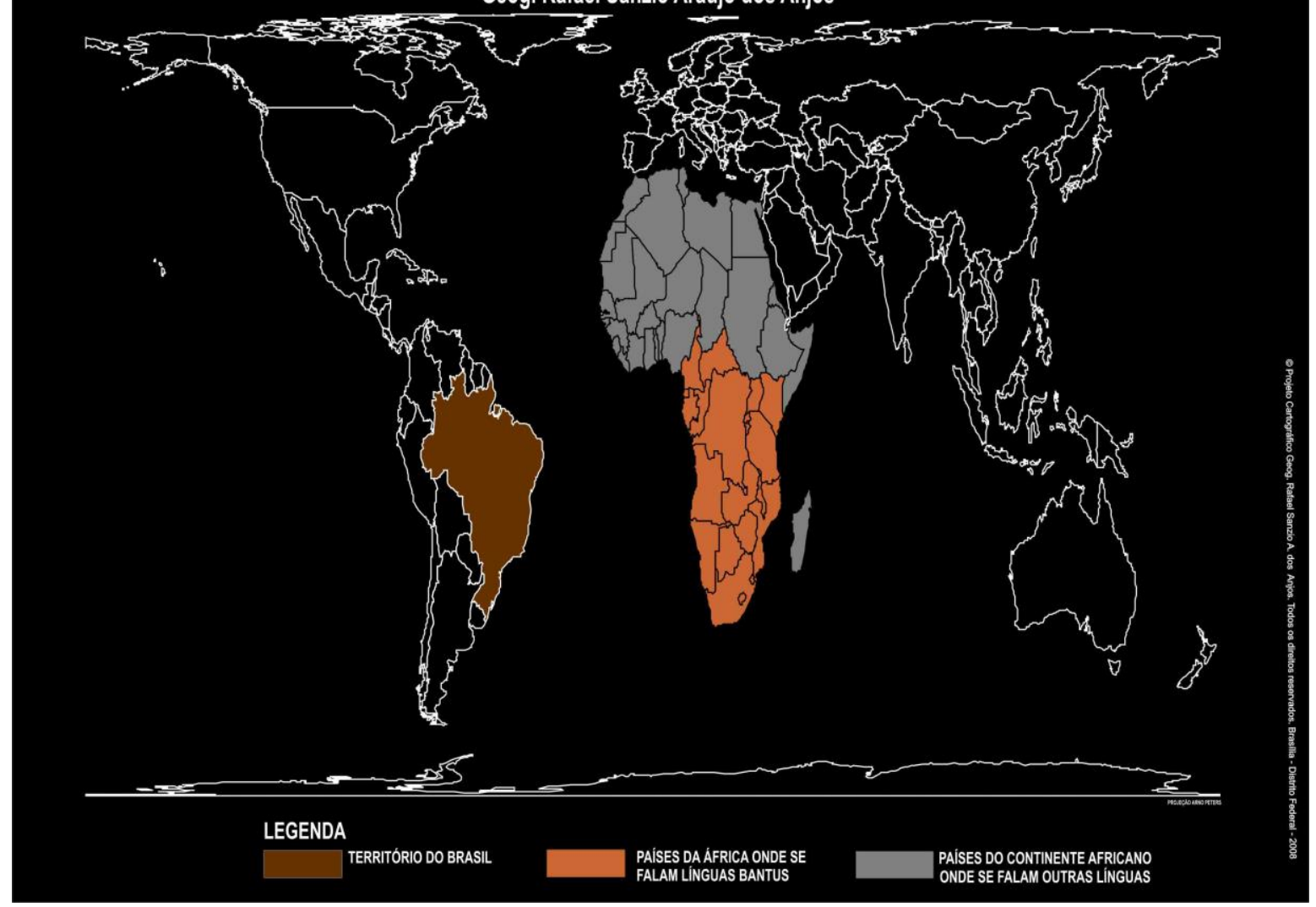

Figura 8: O Brasil e os países Africanos onde se falam línguas Bantus

A cartografia da população contemporânea de matriz africana, mostra a expansão e a consolidação do "Brasil Africanizado" em toda a sua extensão continental. A predominância da matriz Bantu, expressão que significa "as pessoas" ou "seres humanos", revela a sua importância na nossa formação cultural e identitária. Ao longo do século XX vai ficar mais evidenciado os registros das distintas línguas africanas no país, constituindo o fato mais importante da transformação da língua portuguesa, sobretudo as marcas significativas das sociedades oriundas da grande bacia do rio Congo e das regiões do extenso Golfo da Guiné, com influência expressiva no nosso linguajar cotidiano. Algumas expressões de origem Bantu, por exemplo, continuam bem integradas e presentes no nosso cotidiano como: carimbo, quitanda, corcunda, caçula, cachaça, cachimbo, canjica, capanga, dendê, dengo, fubá, ginga, macaco, gangorra, macumba, maculêlê, minhoca, molque, quiabo, dentre outras, constituem uma pequena mostra do português afro-brasileiro (Castro, 
2001).

As estatísticas apontam o Brasil como a segunda maior nação negra do planeta e é com relação a essa população que são computadas as estatísticas mais discriminatórias e de depreciação socioeconômica. Nos piores lugares da sociedade e do território, com algumas exceções, estão as populações afro-brasileiras. Não é possível mais esconder que temos diferenças sociais, econômicas, territoriais seculares e estruturais, para as quais os "remédios" ainda estão chegando e os assuntos são empurrados para um outro dia, para a próxima semana, no mês que vem, no próximo ano, que nunca chega. E os séculos estão passando!

Algumas referências historiográfica do imperialismo e da importância das relações da Bélgica com a R. D. Congo e o Brasil Africano, são tratadas no item a seguir.

\section{A TRAMA DO IMPERIALISMO, O CONGO, A BÉLGICA E O BRASIL AFRICANO - ALGUMAS RELAÇÕES}

Durante três séculos , XVI a XVIII, praticamente não houve oposição na Europa ao tráfico de povos africanos para a América. A Inglaterra, que mais tarde lideraria o abolicionismo no mundo, já iniciava uma campanha contra o comércio de escravos, ainda que indiretamente. A acumulação primitiva de capital podia considerar encerrado seu ciclo, pelo menos neste país, onde o processo estava adiantado. Daí para frente, a própria exploração dos trabalhadores nas fábricas iria assumir o papel principal na reprodução do capital. A política abolicionista inglesa, depois incorporada nos meados do século XIX pelos franceses, holandeses, belgas e alemães, servia para mascarar um projeto político mais ambicioso e mais complexo: o domínio efetivo dos territórios da África e da Ásia. O capitalismo já começara a por de lado a mão-de-obra escrava da África, negócio rendoso em que o interesse europeu estava orientado até o século XIX, embora continuasse desejoso de produtos básicos tropicais das colônias, como, borracha, cobre, manganês, amendoim, cacau, café, açúcar e outras matérias primas, sem as quais o capitalismo industrial não poderia continuar se desenvolvendo.

A necessidade econômica de ampliar o fornecimento de matérias-primas para atender às nações insatisfeitas da Europa; o aumento do prestígio nacional e a busca de 
solução para o problema do crescimento demográfico europeu, se constituíam nos fatores fundamentais para o movimento de ocupação efetiva do território africano no final do século XIX. O processo de "invasão territorial" foi desencadeado por duas estratégias: a religião, com o envio de missionários e, a ciência, com a expansão e financiamento das sociedades geográficas para conhecimento e mapeamento do continente de "penetração complicada". Entre novembro de 1884 e fevereiro de 1885, Bismark, Ministro da Alemanha, país que chegou tardiamente para o desenvolvimento do capitalismo e, em consequência, chegara à África depois dos ingleses, portugueses, franceses, holandeses e belgas, vai promover um encontro estratégico com monarcas, estadistas e diplomatas europeus, evento que ficou conhecido como a "Conferência em Berlim" e cujo principal objetivo era ajustar as diferêncas internas do imperialismo para "dividir" o território africano. Estas ações devastadoras de parcelar o continente sem o respeito à suas unidades lingüísticas e mosaicos étnicos-culturais das sociedades africanas, vai dar início a um outro período violento da história recente da humanidade e o principal pilar da desestruturação social profunda, que vai se desencadear na África.

Dessa forma, vão tomar impulso os grandes investimentos de mineração e agrícolas, sob o comando e responsabilização das companhias concessionárias. A livre iniciativa do grande capital passa a ser a tônica da dominação, representada pela intensificação do trabalho forçado em todo o continente. Este é o momento que a África deixa de ser fornecedora de seres humanos, para exploração do seu trabalho e tecnologia e suas sociedades passam a ser exploradas e desestruturadas no seu próprio território. A cartografia da "Partilha da África", com as suas fronteiras de referência européias, portanto retilíneas e geométricas, mostra a divisão geopolítica efetivamente acordada entre as potências européias no final do século XIX e início do século XX.

Algumas constatações espaciais dessa divisão, meramente européia, são relevantes de serem notadas:

1. O espaço de controle francês vai se concentrar no noroeste e no centro da África e na ilha de Madagascar;

2. A Inglaterra, mais pretenciosa, assegura extensas áreas no eixo norte sul do continente, com outros territórios pulverizados no golfo da Guiné e no extremo oeste;

3. A Bélgica garante a extensão territorial que ocupa toda a bacia do rio Congo; 
4. Os portugueses garantem os territórios de Angola e Moçambique na África Austral;

5. A região do deserto da Namíbia é delimitado de forma geométrica para ser dominada pelo alemães;

6. A Espanha e a Itália, são as duas nações imperialistas, que aparecem com espaços mais restritos.

Revista Eletrônica: Tempo - Técnica - Território, V.1, N.3 (2010), P. 1:25 ISSN: 2177-4366 


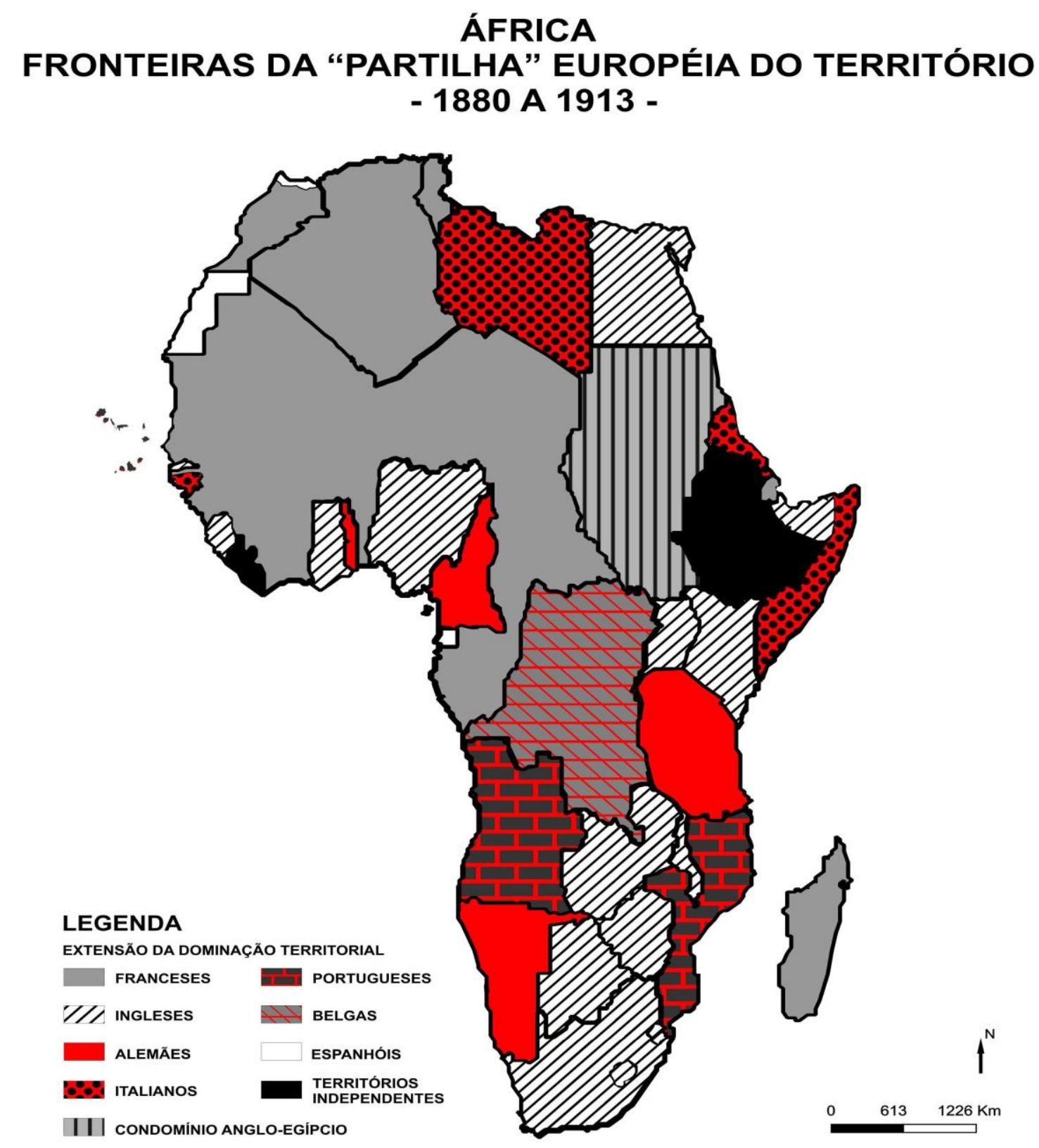

๑) Projeto Geografico by Geógrafo Rafael Sanzio A. dos Anjos. Projeto Geografia Afro-Brasileira. ClGA - UnB. Auxiliar Técnica: Fabiana de Oliveira Hessel I
Rafael Farias da Silva /Rafael Lemes Guimarâes Brasilia - Distrito Federal - 2005 FONTE: ANJOS, R.S.A. A Utilizaçăo dos Recursos da Cartografia Conduzida para uma Africa Desmistificada. Revista Humanidades. Editora UnB (22): 12-32, 1989. I Atlas Des 193 Etats du Monde - Edition Quest - France. 2003

Figura 9: África: Fronteiras da "partilha" Européia do território - 1880 a 1913

Por que a Bélgica é atualmente um país relevante para o Brasil, do ponto de vista da historiografia das relações África-Brasil? O ponto central é que a grande bacia hidrográfica do rio Congo foi o espaço geográfico de origem de um número significativo de grupos 
étnicos Bantus que foram trazidos para a formação do território brasileiro ao longo de quase quatro séculos e a Bélgica foi o pais europeu que dominou e conheceu do fim do século XIX e ao longo do século XX a maior parte desse território e suas sociedades (juntamente com Portugal e a França). Uma relevante estimativa recente destaca que dos quatro milhões de indivíduos transplantados da África Sub-Sahariana para o trabalho escravizado no Brasil, 75 por cento foram trazidos do mundo Bantu falante, de territórios situados atualmente em Angola e nos dois Congos (Castro, 2008 citada por Melo)). Dessa maneira, a República Democrática do Congo (antigo Zaire) se evidencia como uma importante referência historiográfica para o Brasil e a Bélgica, como um país europeu, que aparentemente, não tinha relações evidentes com o Brasil, se configura neste momento histórico, como uma unidade política fundamental para a evolução e aprofundamento das pesquisas e das relações Congo-Brasil, sobretudo pelas possibilidades de se incrementar

políticas de parcerias, intercâmbios e trocas de informações. O Museu Real da África Central é um bom exemplo desta possíbilidade, pelo significativo acervo etnográfico, histórico, cartográfico e de bases de dados automatizados.

Algumas fotografias com referências no Brasil Africano e o Congo são mostradas no item a seguir.

\section{O BRASIL - O CONGO - A BÉlgICA: ALGUNS REGISTROS FOTOGRÁFICOS DAS TRANSFERÊNCIAS AFRICANAS}


REGISTROS FOTOGRÁFICOS DA REPÚBLICA DEMORÁTICA DO CONGO - ÁFRICA\& O BRASIL - AMÉRICA DO SUL - ALGUNS ASPECTOS ARQUITETÔNICOS E DE ESTRUTURA ESPACIAIS EM COMUNIDADES TRADICIONAIS -

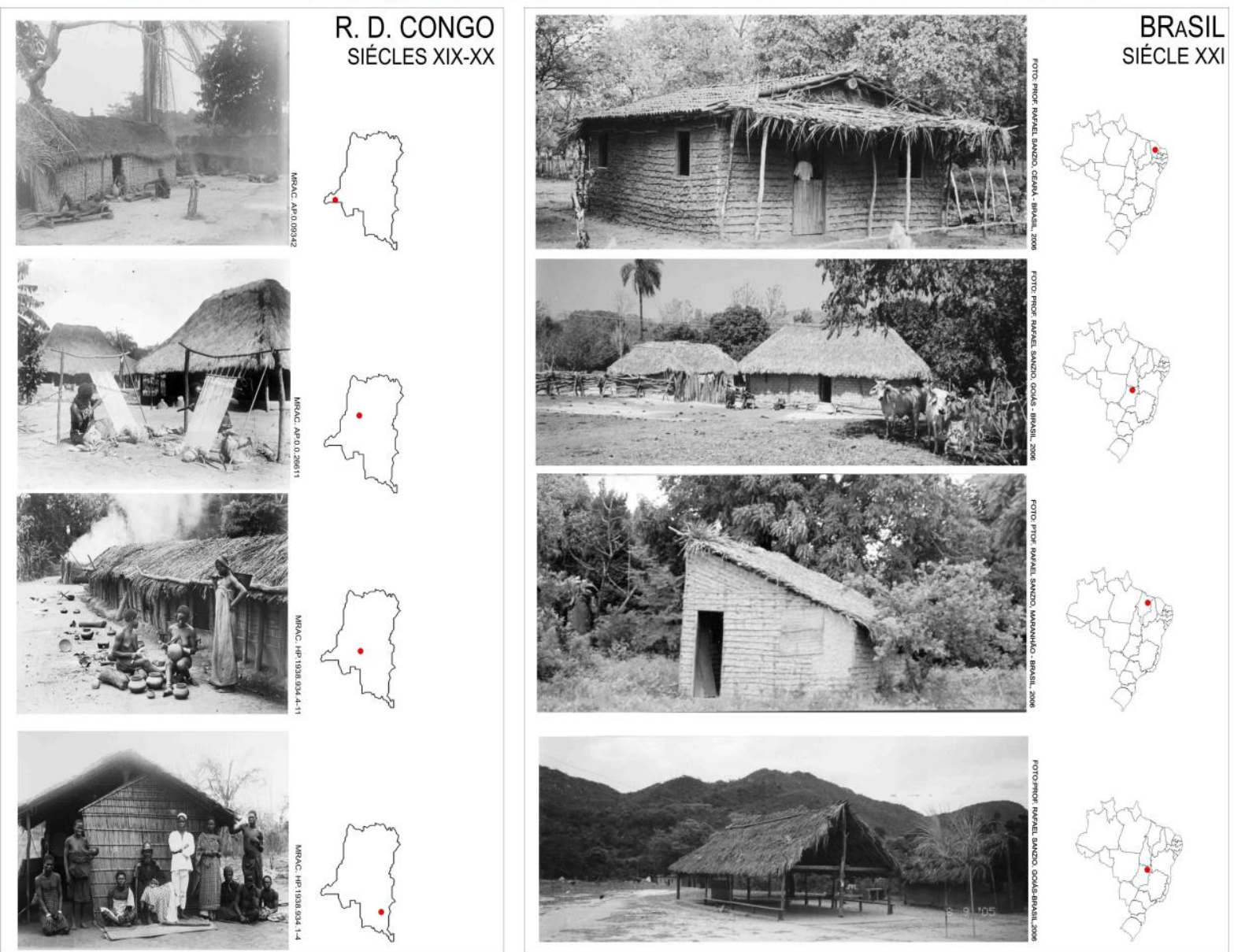

Figura 10: Registros fotográficos da República Democrática do Congo - África e o Brasil - América do Sul 


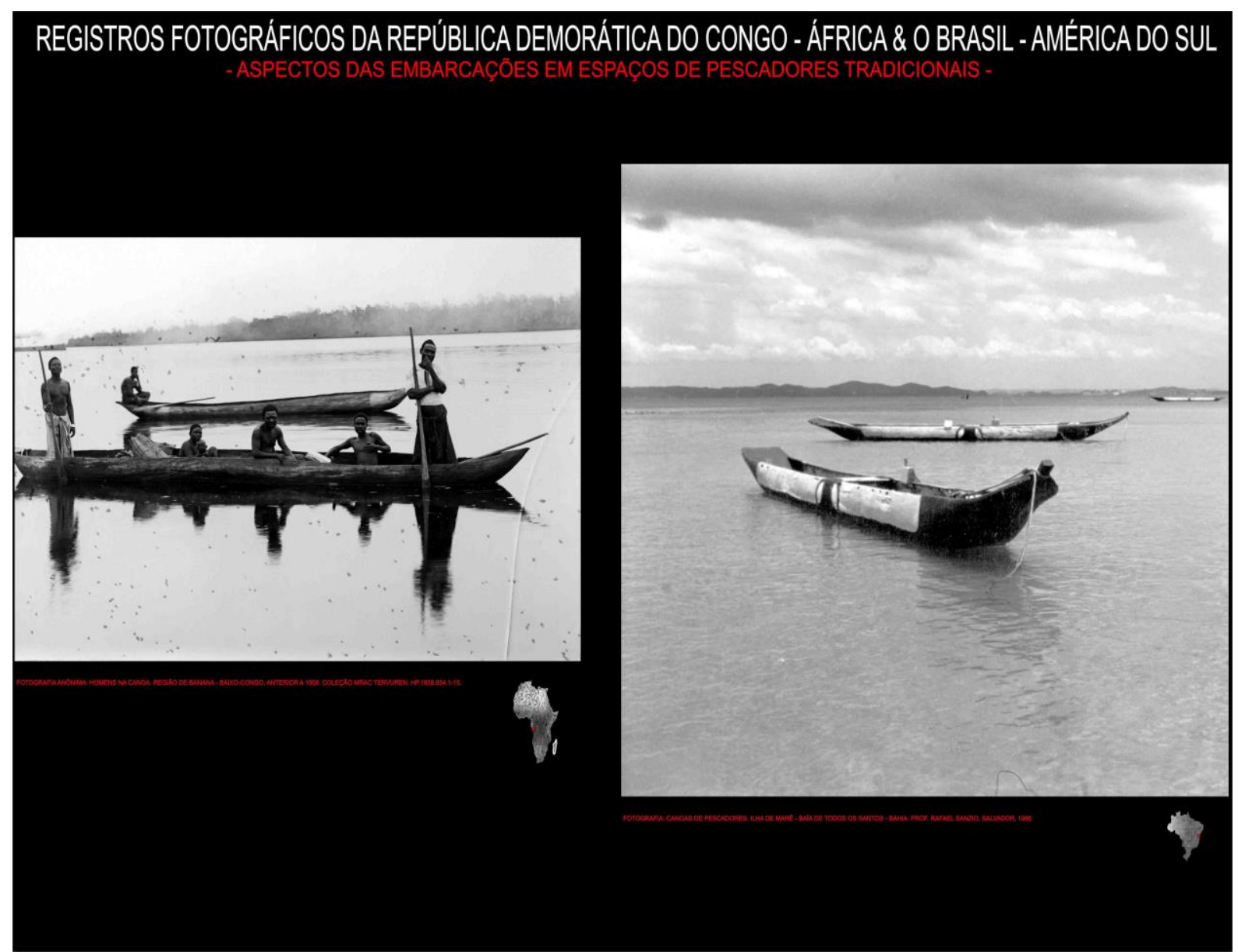

Figura 11: Figura 10: Registros fotográficos da República Democrática do Congo - África e o Brasil América do Sul

\section{REFERÊNCIAS BIBLIOGRÁFICAS}

ANJOS, R. S. A. “A utilização dos recursos da cartografia conduzida para uma África desmistificada”. Revista Humanidades. Brasília: Editora Universidade de Brasília, 6 (22): 12-32, 1989.

“A geografia, os negros e a diversidade cultural”. Série O Pensamento Negro em Educação - Núcleo de Estudos Negros. Florianópolis, 1998, p. 93-106 . “A geografia, a África e os negros brasileiros". In: MUNANGA, K. (org.). Superando o racismo na escola. Brasília: Ministério da Educação, Secretaria de Educação Fundamental, 1999, p. 169-182.

."Distribuição espacial das comunidades remanescentes de quilombos do Brasil”. Revista Humanidades. Brasília: Editora Universidade de Brasília, 9 (47): 
87-98, 1999.

“A África, a geografia, o tráfico de povos africanos e o Brasil. Revista Palmares em Ação. Brasília: Fundação Cultural Palmares - MINc. Ano 1 No.2 : 5666,2002

“Coleção África-Brasil: Cartografia para o ensino-aprendizagem”. Brasília: Mapas Editora \& Consultoria, 2a . Edição. 2005 - BsB - DF.

"Territórios das comunidades remanescentes de antigos quilombos no Brasil - Primeira configuração espacial”. Brasília: Mapas Editora \& Consultoria, $3^{\mathrm{a}}$. Edição. 2005 - BsB - DF.

"Territórios das comunidades quilombolas do Brasil - Segunda configuração espacial. Brasília: Mapas Editora \& Consultoria. 2005 - BsB - DF. . Geografia, território étnico e quilombos. In: GOMES, N. L. (org.). “Tempos de lutas: as ações afirmativas no contexto brasileiro”. Brasília: MEC-Secad, 2006, p.81-103. ANJOS, R.S.A \& CYPRIANO, A. “Quilombolas - tradições e cultura da resistência”. Aori Comunicações. Petrobras, 2006. São Paulo, 240 p.'”

ANJOS, R.S.A. Coleção África-Brasil: Cartografia para o ensino-aprendizagem. Volume II Brasília: Mapas Editora \& Consultoria, Brasília, 2007.

Cartografia \& Educação. Volume I Brasília: Mapas Editora \& Consultoria, Brasília, 2007.

África-Quilombos-Brasil: Átlas Geográfico. Relatório Final de PósDoutorado em Cartografia Étnica. Universidade de Brasília - GEA - CIGA / CNPQ / Museu Real da África Central MRAC - Tervuren. Bruxelas - Bélgica, 2008.

Quilombos: Geografia Africana-Cartografia Étnica-Territórios Tradicionais. Mapas Editora \& Consultoria, 190p. Brasília, 2009

CARRIL, L. F. B. “Territórios negros: comunidades remanescentes de quilombos no Brasil”. AGB Informa no.67. São Paulo,1997, p. 6-7.

CASTRO, Y. P. "Falares africanos na Bahia - um vocabulário afro-brasileiro”. Academia Brasileira de Letras. Rio de Janeiro: Topbooks, 2001, 366p.

IBGE. Pesquisa Nacional por Amostra de Domicílio. Rio de Janeiro: IBGE - PNAD, 1996 MELO, A. Setenta e cinco por cento dos escravos levados para o Brasil eram Bantu. Jornal de Angola, 10/9/2008. Luanda - Angola. 
MINISTÉRIO DA SAÚDE. "Saúde da população negra no Brasil - Contribuições para a promoção da equidade”. Brasília: MS, 2004

\section{AGRADECIMENTOS}

Inicialmente gostaria de agradecer à Equipe Técnica do Centro de Cartografia Aplicada e Informação Geográfica da Universidade de Brasília, ao CNPQ e ao Museu Real da África Central (Tervuren-Bélgica), pelos apoios institucionais e financeiros para o desenvolvimento da pesquisa de Pós-Doutoramento em Cartografia Étnica no período 2007-2008. Particularmente a Johan Lavreau, Sabine Cornelis e Danielle de Lame, pela supervisão e facilidades colocadas. Finalmente agradeço a todos os anjos que me acompanham e a todos os quilombos.

(*) Este artigo é uma versão simplificada da conferência "O Brasil Africano: População e Território", proferida no Museu Real da África Central (MRAC) em Tervuren - Bélgica, no dia 18 de novembro de 2008, dentro das atividades do Programa de Pós-Doutoramento em Cartografia Étnica, junto a esta instituição, com o apoio da Universidade de Brasília e do CNPQ. 